\title{
Service Sector: Methodological Instruments for Managing Enterprise's Image
}

\author{
Bashmachnikova Elena Valentinovna \\ Bakanova Elena Mikhailovna \\ Volga Region State University of Service, Samara region, \\ 445677, Tolyatti, Gagarin's street, 4
}

\section{Doi:10.5901/mjss.2015.v6n3s2p650}

\begin{abstract}
One of the most important factors that provide stable development of country and regions' economy is efficiency and competiveness of enterprises of service sector; in such case primary attention is paid to improvement of instruments and management engineering with the aim of increasing efficiency of its economical activity. Success of service companies depends both on degree of development of market, financial and other production industries, and built image of the enterprise. In this connection, such circumstances require search for new solutions, examination of peculiarities of competiveness' formation and management of service companies' image. Considering the complexity and many-sidedness of the process of image managing, as well as the implications regarding conceptual bases of image managing, this article presents methodological instruments, including the procedure of multi-aspect analysis of condition of service companies' image managing.
\end{abstract}

Keywords: service sector, competiveness, intangible assets, image of the enterprise, instruments of managing.

\section{Introduction}

Development of internationalization and globalization of world economy, as well as modern social and economical conditions for development of regional institutes have determined the tendency of complication and enlargement of market relations, which is primarily connected with:

- quickness and immensity of technological changes;

- with shift in priorities of economic entities' development from material and financial factors to intangible assets;

- $\quad$ with accelerated growth of service sector in comparison with material manufacture;

- with occurrence of new services on the market, development of technology of their provision, and, accordingly, marketing of service sector;

- with definition of intangible assets as instruments for increasing income and consolidation of competitive position of the enterprise (Yerokhina \& Korchagin, 2012).

All these market processes indicate the necessity of promoting services on the market together with tangible product. Along with conventional activities on market research, building of marketing strategy, development of long-term and short-term plans for development of service companies, some attention should also be paid to company's image, since considering specific nature of the services themselves, consumers pay growing attention to this factor while making a choice.

Competitive battle in service sector is performed not only and not so much between the results of the activity, but more between the opinions regarding images of the enterprises (Fomina, 2008). This means that image managing is one of the most important strategic management problems of the companies, working in service sector.

Switch to such enterprise management implies formation of new theoretical and application-oriented problems, which predetermines the necessity to develop understanding of concept of service company's image management, as well as its implementation (Vishnyakova, 2001). 


\section{The Main Part}

Current stage of Russia's development indicates that there appear new, civilized approach to innovational modern business ideas that come from young and creative managers. Today, in order to correspond to current level of development of market environment, using modern technologies and equipment is not enough; the efforts should be directed to other, more strategic level. Nowadays management and marketing of service sector become more topical subject matter, which is considered to be the infrastructure of social activity, aimed at satisfaction of social and spiritual needs of the humankind (Bashmachnikova \& Abramova, 2013).

The art of managing modern service company could be called as one of the most difficult intellectual spheres of human activities. Examining common management practice, one may note that the majority of enterprises focused on such trends as financial management, advertisement (promotion of one's goods and services and provision of security. However, company management in conditions of contemporary dynamic and unpredictable environment requires actualization of unique intangible assets, such as image of service company (Low \& Fullerton, 1994).

Image becomes a pre-requisite for achieving stable and long-lasting business success. This is explained by the fact that, first, company's image gives an effect of acquiring some market force, second, image lowers interchangeability of services, which allows fortifying positions regarding interchangeable services. Third, image facilitates company's access to various resources, like financial, informational, human resources etc. (Lewis, 2003).

Researches on evolution of structural elements of "image" definition, and analysis of conceptual approaches to construing "management" category allowed the author to interpret service company's image management in the following way: this is working-out, confirmation and implementation of management solutions in the process of specific features' formation, which create advantages in effectiveness of application of enterprise's potential, and which define conditions for dynamic growth in competitive environment relative to other competitive objects that satisfy specific needs of groups that perceive image in services.

Considering the complexity and many-sidedness of this process, let us note that nowadays the development of new complex methodological instruments for assessment of service company's image management acquires crucial importance.

Performed comparative analysis of theoretical concepts of company's image management, suggested by M.V. Tomilova, I.A. Aleshina and M. Vishnyakova allowed to detach provisions in the concept of service company's image management, which consider: a) specific peculiarities of mentioned area; b) revised sequence of implementation of the process of service company's image management; $b$ ) leading role of provision in the process of service company's image management (Vishnyakova, 2001; Aleshina, 1998; Tomilova, 1998).

Considering implications, formed basing on the results of theoretical investigation, the stages of multi-aspect analysis of condition of service company's image management were defined, which are demonstrated on Figure 1.

Thus, the procedure of analysis of service company's image management is a consecutive realization of a complex of analytical procedures, which are united in three blocks: preparatory, analytical and problematic one.

Preparatory block of multi-aspect analysis of condition of service company's image management implies definition of targets and tasks of image managing, as well as the development of analysis program, definition of times of delivery and performers of analytical procedures.

The aim of analysis of condition of service company's image management is recognition of problematic areas in the course of realization of this process, and also working-out recommendation as for elimination of recognized issues, directed at increasing of trust among groups that perceive image of the enterprise. 


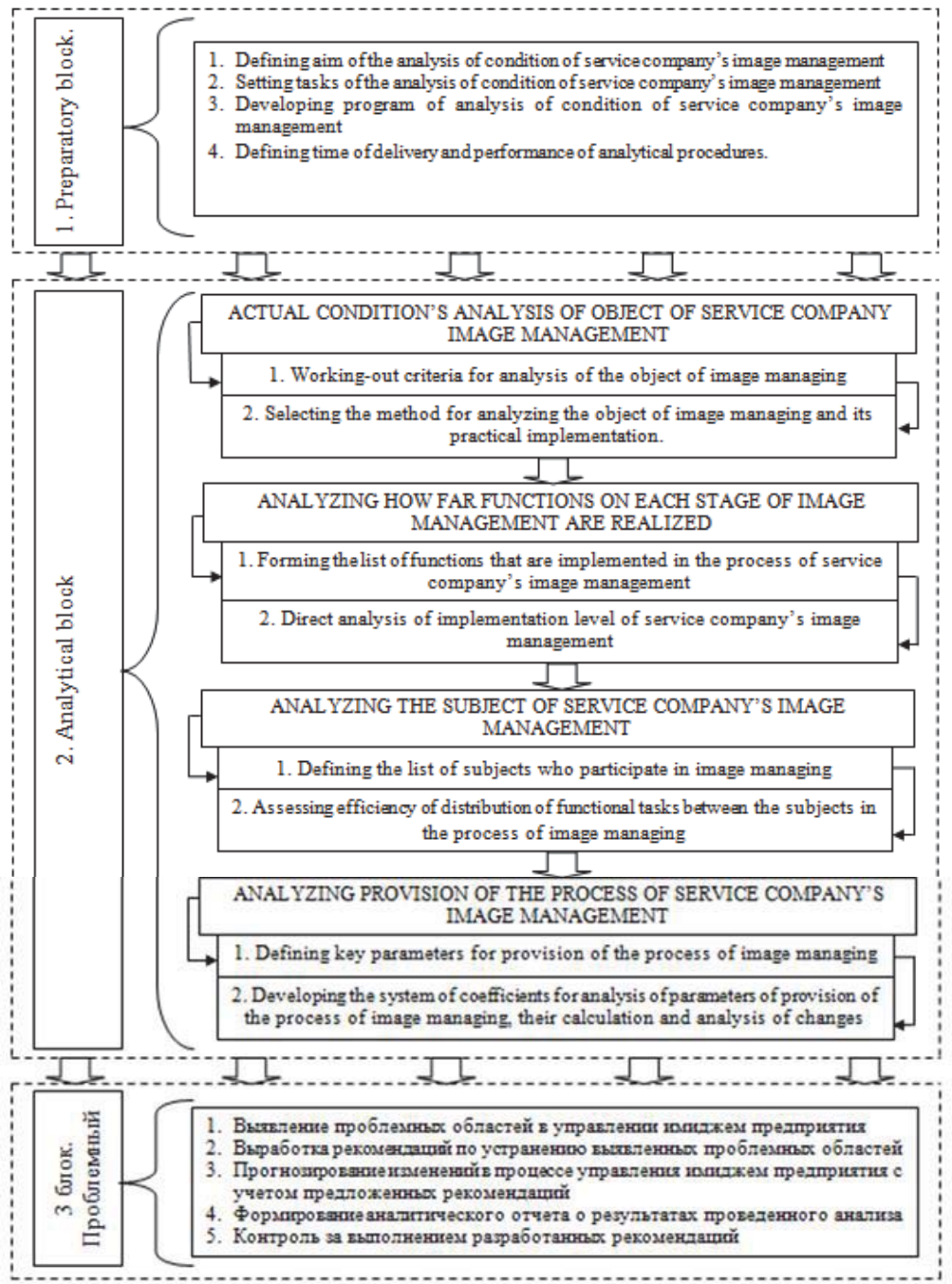

Figure 1. The process of multi-aspect analysis of condition of service company's image management

Such analysis includes the following tasks:

- assessment of possibilities to increase the volume of service implementation, connected with changes and improvements of structural elements of enterprise's image;

- analysis of enterprise's internal potential as for formation and maintaining favourable image of the company;

- defining positions of the enterprise on service market;

- taking management decisions regarding changes and improvement of communication with target groups of image perception etc.

At analytical stage, procedures of multi-aspect analysis of condition of service company's image management the following types of analysis are performed:

1. Analysis of actual condition of the object of service company's image management (image and its structural elements) (Argenti \& Druckenmiller, 2004);

2. Levels of implementation of functions on the stages of managing the image of service company;

3. Subject of service company's image management (Yaniv \& Farkas, 2005); 
4. Provision of the process of service company's image management.

When all analytical calculations within the scope of problematic block of multi-aspect analysis are performed, the following steps are taken:

- Revealing problematic areas in management of enterprise's image

- Working-out recommendations as for eliminating detected problematic areas

- Changes' forecasting in the process of service company's image management, with considerations of suggested recommendations

- Formation of analytical report regarding the results of performed analysis

- Monitoring how recommendations are carried out (Keller, 2005).

According to suggested structure of multi-aspect management analysis, it is possible to assess each element in details and analyze image management in complex; obtained data may be widely used.

Image of the enterprise, in terms of its improvement, influences formation of opinion regarding reliability and stability of the service company, which is one of the essential factors of successful enterprise development, giving characteristics of its reliability (Balmer, 2001). Based on this assumption, we would conclude that enterprise's image serves as a reliability index, and multi-aspect analysis of which may be performed as an addition to existing indices of competiveness of the service company.

\section{Summary}

Thus, in conditions of market transformations, image becomes a necessary compound for achieving enterprise's stability and success; in its turn, methodology of managing company's image allows defining cause-and-effect relations and hierarchy of the factors that facilitate service company's growth. Presented provisions create basis for managing company's image, which favours its competiveness' growing and effectiveness boost of its activities in service sector.

\section{Conclusions}

The article presents the definition of service company's image management, which develops theoretical model of studied range of problems in terms of endowing this process with functional content and identification of key advantages of formation of image elements complex of service company.

Provisions of the concept allow making existing theoretical concepts more specific and profound by means of specification of stages of image management process, and also by means of provision of this process by priority functions for the purposes of rational solution of tasks related to service company's image management. We have defined procedures of multi-aspect analysis of condition of service company's image management, united into three blocks: preparatory, analytical and problematic ones. The instruments implemented within the scope of analytical block the following ones are presented: 1) method of complex analysis of service company's image management; 2) methodology of analyzing levels of implementation of function in the process of service company's image management; 3) assessment matrix in terms of effectiveness of functional tasks' distribution between the subjects in image management process; 4) methodology of calculating coefficients that characterize provision of image management process.

Importance of presented theoretical provisions, as well as developments of practical instruments for managing image of service company lies in possibility of using results as initial material for further scientific and methodological developments in the sphere of service company's image management.

\section{References}

Aleshina, I.V. (1998). Strategic aspect of corporate image. Marketing in Russia and Abroad, 1, $44-50$ (In Russuan).

Argenti, P.A., \& Druckenmiller, B. (2004). Reputation and the corporate brand. Corporate Reputation Review, 6 (4), 368-374.

Balmer, J.M.T. (2001). Corporate identity, corporate branding and corporate marketing: seeing through the fog. European Journal of Marketing, 35 (3/4), 248-291.

Bashmachnikova, E.V., \& Abramova, L.A. (2013). Service sector: definition, classification, tasks. Problems of Theory and Practice of Management, 2, 123-130 (In Russuan).

Fomina, E.V. (2008). Managing company's business image in modern Russian economy. Marketing in Russia and Abroad, 1, 46-53 (In Russuan).

Keller, K.L. (2005). Strategic brand management: building, measuring, and managing brand equity. 2-nd Ed., Transl. from Eng. Moscow: Williams Publishing House

Lewis, S. (2003). Reputation and corporate responsibility. Journal of Communication Management, 7 (4), 356-364. 
Low, G., \& Fullerton, A. (1994). Brands, brand management, and the brand manager system: A critical-historical evaluation. Journal of Marketing Research, 31, 173-190.

Tomilova, M.V. (1998). Model of organization's image. Marketing in Russia and Abroad, 1, 5-17 (In Russuan).

Vishnyakova, M. (2001). Concept of formation of company's image (general approach and recommendations). Practical Marketing, 5 , 55-67

Yaniv, E., \& Farkas, F. (2005). The impact of person-organization fit on the corporate brand perception of employees and of customers. Journal of Change Management, 5 (4), 447-461.

Yerokhina, L.I., \& Korchagin, P.V. (2012). Problems of territory's economical and social development. Bulletin of Volga Region State University of Service. Series "Economics", 6 (26), 49-53 (In Russuan). 